\title{
Predicting 24-hour Urinary Sodium Excretion in Afro-Caribbean Barbadians by Comparing Urine Sodium Excretion over Different Durations versus Spot Collection
}

\author{
DH Cohall ${ }^{1}$, T Scantlebury-Manning ${ }^{2}$, C Nakhleh ${ }^{3}$, D Toure ${ }^{3}$, S James ${ }^{4}, \mathrm{~K}_{\text {Hall }}^{1}$
}

\begin{abstract}
Aim: Urinary sodium excretion is used as an assessment tool for salt intake and salt handling. Even though cumbersome, the most reliable and readily used method in clinical and epidemiological studies is the 24-hour urine collection. This study investigates other appropriate means of predicting 24-hour urinary sodium excretion in a sample of Afro-Caribbeans in Barbados by assessing the correlation of actual and estimated urinary sodium excretion between a 24-hour urine collection sample, 12-hour (AM and $P M)$, and spot (AM and $P M)$ urine collections.

Method: A convenient sample of 30 healthy participants of Afro-Caribbean origin between the ages of 21 and 55 years was recruited for the study. The 24-hour urine samples and anthropometric data were collected as documented in the study's standard clinical procedure. A 24-hour urine sample was collected as two separate 12-hour AM and PM samples. In addition, two spot samples (AM and PM) were taken during each 12-hour sample collection period. Analysis of the urinary sodium and creatinine was done with a Roche/Hitachi Modular System (Roche Diagnostics, IN, USA). SPSS version 19 was used to analyse the data to make inferences.

Results: Thirty Afro-Caribbean subjects participated in this study: 16 females and 14 males. The average age and body mass index (BMI) were $38 \pm 17$ years and $25.32 \pm 5.98 \mathrm{~kg} / \mathrm{m}^{2}$, respectively. The greatest correlation of the estimated 24-hour sodium excretion to the measured 24-hour sodium excretion was observed in the 12-hour PM sample (Pearson's correlation, $r=0.786, \mathrm{p}<0.001$ ) followed by the 12-hour AM sample (Pearson's correlation, $r=0.774, p<0.001$ ). The PM spot sample showed a weaker, but still statistically significant correlation to the 24-hour timed sample (Pearson's correlation, $r=0.404, \mathrm{p}<0.045)$. The AM spot sample showed a very weak and insignificant correlation (Pearson's correlation, $r=0.05, \mathrm{p}=0.807$ ) to the 24-hour timed sample. Similarly to the whole sample, the gender analysis demonstrated that estimated 24-hour sodium excretion in the female's 12-hour PM sample had the greatest correlation $(r=0.819, \mathrm{p}<0.001)$ to the measured 24hour sodium excretion, followed by the 12-hour AM $(r=0.793, \mathrm{p}=0.001)$ and the PM spot samples $(r=0.741, \mathrm{p}=0.02)$. The correlation between variables is weaker in males compared to the females. Conclusion: Overall, this study shows a clear correlation between the estimated 24-hour sodium excretion from the 12-hour timed PM sample and the measured 24-hour sodium excretion. Such findings support the thought of using other alternatives to determine sodium excretion, in view of replacing the cumbersome 24-hour urinary collection with a smaller timed sample. Nonetheless, a more robust and randomized population sample as well as a method to correct for high creatinine variability is required to further enhance the significance of the obtained results.
\end{abstract}

Keywords: Afro-Caribbean, creatinine, excretion, sodium, urinary

\section{Predicción de la Excreción del Sodio Urinario de 24 Horas en Barbadenses Afrocaribeños Mediante la Comparación de la Excreción del Sodio en la Orina en Diferentes Periodos de Tiempo en Contraste con la Recogida al Azar}

DH Cohall ${ }^{1}$, T Scantlebury-Manning ${ }^{2}, \mathrm{C} \mathrm{Nakhleh}^{3}$, D Toure ${ }^{3}$, S James ${ }^{4}, \mathrm{~K}$ Hall $^{1}$

From: ${ }^{1}$ Faculty of Medical Sciences, ${ }^{2}$ Faculty of Science and Technology, The University of the West Indies, Cave Hill, Barbados, ${ }^{3}$ Department of Dietetics, McGill University, Montreal, Canada and ${ }^{4}$ Barbados Community College, St Michael, Barbados.
Correspondence: Dr D Cohall, Faculty of Medical Sciences, The University of the West Indies, Cave Hill, Barbados. Fax: (246) 438-9170, e-mail: damian.cohall@cavehill.uwi.edu 


\section{RESUMEN}

Objetivo: La excreción del sodio en orina se utiliza como una herramienta de evaluación para la ingesta y manejo de la sal. Si bien resulta engorroso, el método más fiable y fácilmente utilizado en los estudios clínicos y epidemiológicos es la recolección de orina de 24 horas. Este estudio investiga otros medios apropiados de predicción de la excreción del sodio urinario de 24 horas en los afrocaribeños en Barbados, evaluando la correlación real y estimada de la excreción del sodio en orina entre una muestra de orina de 24 horas, 12 horas (AM y PM), y recogidas aleatorias (AM y PM).

Método: Una muestra conveniente de 30 participantes sanos de origen afrocaribeño entre las edades de 21 y 55 años, fue reclutada para el estudio. Las muestras de orina de 24 horas y los datos antropométricos, fueron recogidos tal como se documenta en el procedimiento clínico estándar del estudio. Una muestra de orina de 24 horas fue recogida en forma de muestras de 12 horas AM y PM por separado. Además, se tomaron dos muestras (AM y PM) al azar durante cada periodo de recolección de muestras de 12 horas. El análisis del sodio y la creatinina urinarios fue hecho con un Sistema Modular Roche/Hitachi (Roche Diagnostic, IN, USA). La versión 19 de SPSS fue utilizada para analizar los datos para hacer las inferencias.

Resultados: Treinta sujetos afrocaribeños participaron en este estudio: 16 mujeres y 14 hombres. La edad media y el indice de masa corporal (IMC) promedio fueron $38 \pm 17$ años y $25.32 \pm 5.98 \mathrm{~kg} / \mathrm{m}^{2}$, respectivamente. La mayor correlación de la excreción estimada de sodio de 24 horas con la excreción medida de sodio 24 horas, se observó en la muestra de 12 horas PM (correlación de Pearson, $r=0.786$, $\mathrm{p}<0.001$ ), seguida por la muestra de 12 horas AM (correlación de Pearson, $r=0.774, \mathrm{p}<0.001$ ). La muestra aleatoria PM mostró una correlación más débil, pero de todos modos estadís-ticamente significativa con respecto a la muestra cronometrada de 24 horas (correlación de Pearson, $r=0.404$, $\mathrm{p}<0.045)$. La muestra aleatoria AM mostró una correlación muy débil y estadísticamente no significativa (correlación de Pearson, $r=0.05, \mathrm{p}=0.807$ ) con respecto a la muestra cronometrada de 24 horas. De modo similar a la muestra en su totalidad, el análisis de género demostró que la excreción de sodio estimada de 24 horas en la muestra PM de 12 horas de las mujeres, tenía la mayor correlación $(r=0819, \mathrm{p}<0.001)$ con respecto a la excreción de sodio medida de 24 horas, seguida por las muestras de 12 horas AM $(r=0.793, \mathrm{p}=0.001)$ y las muestras PM al azar $(r=0.741, \mathrm{p}=0.02)$. La correlación entre las variables es más débil en los varones en comparación con las hembras.

Conclusión: En general, este estudio muestra una clara correlación entre la excreción de sodio estimada de 24 horas a partir de la muestra PM cronometrada de 12 horas, y la excreción de sodio medida de 24 horas. Estos hallazgos respaldan la idea de utilizar otras alternativas para determinar la excreción de sodio, teniendo en la mira el reemplazar la engorrosa recogida de orina de 24 horas por una muestra recogida en un tiempo menor. No obstante, una muestra de población más sólida y aleatoria, así como un método para corregir la variabilidad de la creatinina alta, son necesarios para mejorar aún más la importancia de los resultados obtenidos.

Palabras clave: Afrocaribeño, creatinina, excreción, sodio, urinario

West Indian Med J 2013; 62 (3): 182

\section{INTRODUCTION}

Urinary sodium (Na) excretion is used as an assessment tool for salt intake and in the assessment of salt handling. The phenotypical representation of salt homeostasis may result from a dynamic interplay between genes and the environment. One major environmental factor influencing renal sodium handling is dietary salt $(\mathrm{NaCl})$ intake.

The two most widely used methods to determine urinary sodium excretion and subsequent salt intake are the measurement of sodium in a 24-hour urine collection and the estimation of sodium excretion from the $\mathrm{Na}$ /creatinine $(\mathrm{Cr})$ ratio in spot urine samples (1). Currently, the most reliable and readily used method in clinical and epidemiological studies is the 24-hour urine collection. Nonetheless, it is considered more cumbersome by research participants and patients. It has also been suggested that daily $\mathrm{Na}$ excretion may vary from day to day which would further require the collection of multiple samples. In contrast, spot urine collections are considered less reliable but more suitable for participants in clinical practice and large studies. Thus, considering the convenience of opting for such a method over a 24-hour urine collection, it is of interest to determine whether a spot urine sample or another timed sample can accurately reflect $\mathrm{Na}$ excretion in a 24-hour urine collection. In fact, several studies have attempted to highlight the benefits of using a spot urine sample. An epidemiological study conducted by Mann et al reported a strong correlation between the late afternoon $\mathrm{Na} / \mathrm{Cr}$ ratio of a spot urine sample with the 
$\mathrm{Na}$ excretion per amount of creatinine in a 24-hour urine sample (2). Similarly, another epidemiological study conducted in the Japanese population evaluated the correlation between a spot sample and a 24-hour urine collection for both sodium and potassium (3). The study established that the urine spot sample was in fact an accurate and time-saving method in measuring the population's mean of sodium and potassium excretion (3).

In addition, the degree of correlation of the measured 24-hour urinary sodium excretion with an estimated 24-hour urinary sodium excretion from a spot sample might be dependent on the degree of the average salt consumption of the population. Afro-Caribbean people are thought to consume relatively higher amounts of dietary sodium. However, noted studies were done with participants mainly of European and Asian descent, hence there is a need to determine if the same is observed in persons of African descent, more specifically the Afro-Caribbean ethnic group.

\section{SUBJECTS AND METHODS}

The study was approved by the Institutional Review Board of the University of the West Indies, Cave Hill campus/Ministry of Health, Barbados. Thirty healthy participants of Afro-Caribbean origin were recruited from both The University of the West Indies campus and the Hilton Barbados. In total, 14 males and 16 females ranging in age from 21-55 years participated in the study. Subjects with at least one of the following criteria were to be excluded from the study: high alcohol consumption (> 14 units women, 21 units men per week) and recreational drug use, smokers for more than a year, diabetes (diagnosed or on fasting blood glucose), hypertension (on medication, so Joint National Committee (JNC) pre-hypertension acceptable), clinically evident vascular disease or a body mass index (BMI) $<18 \mathrm{~kg} / \mathrm{m}^{2}$ or $>36 \mathrm{~kg} / \mathrm{m}^{2}$.

Participants were observed on two separate occasions. Upon the first visit, each participant was provided with a container to collect a 24-hour urine sample. During the second visit, anthropometric measurements were noted and urine samples were returned.

The 24-hour urine sample was collected as documented in the study's standard clinical procedure. Hence, a 24-hour urine sample was collected as two separate 12-hour AM and PM samples. In addition, two spot samples (AM and PM) were taken during each 12-hour sample collection period. The AM spot sample was defined as the second urine voided for the day and the PM spot sample was defined as the first urine voided after a 12-hour period (collected in the evening). All volumes were recorded. Fifteen millilitres $(15 \mathrm{mLs})$ of all samples were submitted to the Chemical Pathology Laboratory at the Queen Elizabeth Hospital, Bridgetown, Barbados for analysis. Analysis of the urinary parameters of sodium and creatinine was done with a Roche/Hitachi Modular System (Roche Diagnostics, IN, USA). SPSS version 19 was used to analyse the data to make inferences.

\section{RESULTS}

Thirty persons participated in this study: 16 females and 14 males. All participants were of Afro-Caribbean descent. The average age and BMI were $38 \pm 17$ years and $25.32 \pm 5.98$ $\mathrm{kg} / \mathrm{m}^{2}$, respectively. The Pearson's linear regression was used to interpret the data. Statistical significance was noted at the $95 \%$ confidence level.

In order to determine the estimated 24-hour urinary sodium from each spot and 12-hour sample, the following equation was used: $\mathbf{N a}_{\text {sample }} / \mathbf{C r}_{\text {sample }}=\mathbf{N a}_{24}$ hour $/ \mathbf{C r}_{24}$ hour . The estimated 24-hour urinary sodium excretion for each sample was then analysed against the measured 24-hour urinary sodium excretion. Pearson's linear correlation coefficient (r) was calculated to assess the relation between parameters. Correlations were considered statistically significant if the $p$-value was below 0.05 . Furthermore, gender sub-groups were analysed for trends.

Table 1 shows the mean measured and estimated 24hour urinary sodium excretion values from the various collected samples.

Table 1: Mean measured and estimated 24-hour urinary sodium excretion values $( \pm \mathrm{SE})$

\begin{tabular}{llcc}
\hline Urine samples & \multicolumn{3}{c}{ 24-hour urinary sodium excretion mmol/L } \\
& Total participants & Female & Male \\
\hline 24-hour urine collection & $147.90 \pm 10.24$ & $147.93 \pm 15.98$ & $147.86 \pm 12.84$ \\
AM spot sample & $160.08 \pm 11.92$ & $155.81 \pm 18.31$ & $166.90 \pm 11.08$ \\
PM spot sample & $153.16 \pm 14.43$ & $162.35 \pm 21.95$ & $141.45 \pm 17.70$ \\
12-hour AM times sample & $140.83 \pm 9.19$ & $129.44 \pm 13.32$ & $154.85 \pm 11.70$ \\
12-hour PM timed sample & $145.21 \pm 11.66$ & $135.25 \pm 15.29$ & $157.46 \pm 18.03$
\end{tabular}

SE - standard error; measured 24-hour urinary sodium values are in italics

Table 2 highlights the correlation between estimated 24-hour urinary sodium and measured 24-hour urinary

Table 2: Correlation between estimated 24-hour urinary sodium and measured 24-hour urinary sodium excretion values

\begin{tabular}{lccc}
\hline & Sample size & $\begin{array}{c}\text { Pearson's } \\
\text { correlation } \\
\boldsymbol{n}\end{array}$ & $\begin{array}{c}\text { Significance } \\
\text { (2-tailed) } \\
\boldsymbol{n}\end{array}$ \\
\hline AM spot sample & 26 & 0.05 & 0.807 \\
PM spot sample & 25 & 0.404 & 0.045 \\
AM 12-hour sample & 27 & 0.774 & 0.000002 \\
PM 12-hour sample & 28 & 0.786 & 0.000001 \\
\hline
\end{tabular}

sodium excretion. Amongst all samples, the greatest correlation was observed in the 12-hour PM sample $(\mathrm{r}=0.786, p$ $<0.001)$ followed by the 12-hour AM sample $(\mathrm{r}=0.774, p<$ 0.001). Also, the PM spot sample showed a weaker, but still statistically significant correlation to the 24-hour measured sodium excretion $(\mathrm{r}=0.404, p=0.045)$. However, the AM spot sample showed a very weak and insignificant correlation $(r=0.05, p=0.807)$ to the measured 24-hour sodium values. 
Table 3 displays the correlation between estimated 24hour urinary sodium and measured 24-hour urinary sodium

Table 3: Correlation between estimated 24-hour urinary sodium and measured 24-hour urinary sodium by gender

\begin{tabular}{|c|c|c|c|}
\hline & $\begin{array}{c}\text { Sample size } \\
n\end{array}$ & $\begin{array}{c}\text { Pearson's } \\
\text { correlation } \\
r\end{array}$ & $\begin{array}{c}\text { Significance } \\
\text { (2-tailed) } \\
p\end{array}$ \\
\hline \multicolumn{4}{|l|}{ Females } \\
\hline AM spot sample & 16 & 0.369 & 0.159 \\
\hline PM spot sample & 14 & 0.741 & 0.002 \\
\hline AM 12-hour sample & 14 & 0.793 & 0.001 \\
\hline PM 12-hour sample & 15 & 0.819 & 0.0002 \\
\hline \multicolumn{4}{|l|}{ Males } \\
\hline AM spot sample & 10 & -0.108 & 0.767 \\
\hline PM spot sample & 11 & 0.451 & 0.164 \\
\hline AM 12-hour sample & 13 & 0.745 & 0.003 \\
\hline PM 12-hour sample & 13 & 0.848 & 0.0003 \\
\hline
\end{tabular}

in the gender sub-groups. The females demonstrated the same relationship as the entire sample. Hence, the 12-hour PM sample had the greatest correlation $(\mathrm{r}=0.819, p<0.001)$, followed by the 12-hour AM $(\mathrm{r}=0.793, p=0.001)$ and the PM spot samples $(\mathrm{r}=0.741, p=0.02)$. The AM spot sample showed weak and insignificant correlation $(\mathrm{r}=0.369, p=$ 0.159 ) to the measured 24-hour urinary sodium excretion. The correlation between variables is weaker in males compared to the females, such that the correlation of the estimated 24-hour urinary sodium excretion from the PM spot sample and the measured 24-hour urinary sodium excretion loses significance in this sub-group.

\section{DISCUSSION}

Several studies comparing estimated urinary sodium excretion in spot urine samples with measured sodium in 24-hour collections have reported a strong correlation between afternoon samples and 24-hour sodium excretion values $(2,9)$. The results of this study support the use of the afternoon 12hour timed samples more so than the afternoon spot sample. Unlike this study, other studies which investigated this research question focussed on Caucasians, Asians or a mixed population in which Afro-Caribbean people were not predominant. As evidenced by Tables 2 and 3, the $\mathrm{Na} / \mathrm{Cr}$ ratio of the 12-hour PM sample is highly correlated with and statistically significant to the 24-hour collection.

An important difference in male and female values is seen. The correlation between variables is weaker in males than in females, such that the correlation of the estimated 24hour urinary sodium excretion from the PM spot sample and the measured 24-hour urinary sodium excretion loses significance. This may be due to the difference in muscle mass between males and females. Males are thought to have more muscle mass than women and consequently larger urinary creatinine levels $(10,11)$. In fact, studies have indicated a high correlation between urinary creatinine concentrations and muscle mass (10-12). Therefore, higher creatinine excretion in males may affect the estimation equation and subsequently the estimated values, thus justifying weaker values in the male sub-group. This finding presents a possible gender limitation in the use of spot/less than 24-hour timed samples in males. A method to correct for the high variability of creatinine should therefore be considered.

Typically, a 24-hour urinary sodium excretion can account for $95 \%-98 \%$ of dietary sodium intake (13). However, studies have determined that within-person variability in sodium excretion may be as high as 30\% (13). The 12hour PM sample provides a wider time span and reflects the 24-hour sodium excretion more accurately than the PM spot sample due to its less likely susceptibility to differences caused by individual's variations in sodium consumption; which can also vary widely in the same person during a short span of time. After consumption of a salty meal, the spot sample collected will most likely have a weaker correlation with the 24- hour collection compared to the 12-hour sample, which better reflects the overall salt consumption during that period of time. Such results highlight the usefulness and effectiveness of using the other options (12-hour timed samples) in predicting 24-hour urinary sodium excretion.

\section{CONCLUSION}

Overall, this study shows a clear correlation between the estimated 24-hour urinary sodium excretion in a 12-hour PM sample and the measured 24-hour urinary sodium values, specifically in the sample of Afro-Caribbean study participants. Such findings support the thought of using alternate sampling measures to determine sodium excretion, in view of replacing the cumbersome 24 -hour urinary collection. Nonetheless, a more robust and randomized population sample as well as a method to correct for high creatinine variability is required to further enhance the significance of the obtained results.

\section{REFERENCES}

1. Coleman A, Freeman P, Steel S, Shennan A. Validation of the Omron 705IT (HEM-759-E) oscillometric blood pressure monitoring device according to the British Hypertension Society protocol. Blood Press Monit 2006; 11: 27-32.

2. Mann SJ, Gerber LM. Estimation of 24-hour sodium excretion from spot urine samples. J Clin Hypertens 2010; 12: 174-80.

3. Tanaka T, Okamura T, Miura K, Kadowaki T, Ueshima H, Nakagawa H et al. A simple method to estimate populational 24-h urinary sodium and potassium excretion using a casual urine specimen. J Hum Hypertens 2002; 16: 97-103.

4. Sartori M, Pessina AC, Semplinichi A. Orthostatic hypotension and supine hypertension in primary autonomic failure. Hypertens 2005; 45: e18-e19.

5. Kario SK, Eguchi K, Nakagawa Y, Motai K, Shimada K. Hypertensive patients relationship between extreme dippers and orthostatic hypertension in elderly. Hypertens 1998; 31: 77-82.

6. Shibao C, Gamboa A, Diedrich A, Biaggioni I. Management of hypertension in the setting of autonomic failure: a pathophysiological approach. Hypertens 2005; 45: 469-76. 
7. Gamboa A, Shibao C, Diedrich A, Paranjape SY, Farley G, Christman $\mathrm{B}$ et al. Excessive nitric oxide function and blood pressure regulation in patients with autonomic failure. Hypertens 2008; 51: 1531-6.

8. Rothwell PM, Howard SC, Dolan E, O'Brien E, Dobson JE, Dahlöf B et al. Prognostic significance of visit-to-visit variability, maximum systolic blood pressure, and episodic hypertension. Lancet 2010; 375: 895-905.

9. Kawamura M, Kusano Y, Takahashi T, Owada M, Sugawara T. Effectiveness of a spot urine method in evaluating daily salt intake in hypertensive patients taking oral antihypertensive drugs. Hypertens Res 2006; 29: 397-402.

10. Barr BD, Wilder LC, Caudill SP, Gonzalez AJ, Needham LL, Pirkle LP. Urinary creatinine concentrations in the US population: implications for urinary biologic monitoring measurements. Environ Health Perspect 2005; 113: 192-200.

11. Baxmann AC, Ahmed MS, Marques NC, Menon VB, Pereira AB, Kirsztajn GM et al. Influence of muscle mass and physical activity on serum and urinary creatinine and serum cystatin C. Clin J Am Soc Nephrol 2008; 3: 348-54.

12. Janssen I, Heymsfield SB, Wang ZM, Ross R. Skeletal muscle mass and distribution in 468 men and women aged 18-88 yr. J Appl Physiol 2000; 89: 81-8.

13. Benthley B. A review of methods to measure dietary sodium intake. J Cardiovasc Nurs 2006; 21: 63-7. 